\title{
WIESŁAW CHARCZUK
}

Instytut Nauk Społecznych i Bezpieczeństwa

Uniwersytet Przyrodniczo-Humanistyczny w Siedlcach

e-mail: acharczuk5@o2.pl

\begin{abstract}
„Obława! Obława! Na młode wilki obława!” Na białych Polaków obława. Wojska NKWD w walce z polskim podziemiem 1944-1953, Wydawnictwo Literackie, Kraków 2014, ss. 516
\end{abstract}

Niedawno na rynku księgarskim ukazała się praca polskiego historyka Grzegorza Motyki, która podejmuje temat podporządkowywania Polski przez ZSRR, zwłaszcza na płaszczyźnie politycznej poprzez zwalczanie podziemia niepodległościowego prowadzone przez Ludowy Komisariat Spraw Wewnętrznych (NKWD), a od III 1946 r. przez Ministerstwo Spraw Wewnętrznych (MWD) i Ministerstwo Bezpieczeństwa Państwowego (MGB), przeciwko polskiemu podziemiu niepodległościowemu. Praca ma układ chronologiczno-problemowy. Data początkowa nie budzi zastrzeżeń, jest związana z wkroczeniem Armii Czerwonej na teren Polski i próbą instalowania, przy wydatnej pomocy Kremla, władzy komunistycznej. W swojej pracy Grzegorz Motyka wykorzystał materiały źródłowe zdeponowane w 10 archiwach, w tym z 2 rosyjskich, 1 białoruskiego, 2 ukraińskich i 5 polskich archiwów².

Cezura końcowa niniejszej publikacji zamyka się na 1953 r. - śmierć Józefa Stalina oraz działania oddziałów MGB, które przeprowadziły akcje likwidacyjne polskiego podziemia o proweniencji $\mathrm{AK}$ na terenie powiatu grodzieńskiego Białoruskiej Socjalistycznej Republiki Radzieckiej. Praca składa się ze wstępu,

1 Wers z piosenki Jacka Kaczmarskiego, Obława.

2 Rosyjskie Państwowe Archiwum Wojskowe; Państwowe Archiwum Federacji Rosyjskiej; Narodowe Archiwum Republiki Białoruś; Centralne Państwowe Archiwum Społecznych Organizacji Ukrainy; Państwowe Archiwum Obwodu Lwowskiego; Studium Polski Podziemnej w Londynie; Archiwum Instytutu Pamięci Narodowej w Warszawie; Instytutu Pamięci Narodowej Delegatura w Kielcach; Instytutu Pamięci Narodowej Oddział w Białymstoku i Centralne Archiwum Wojskowe. 
16 rozdziałów, zamiast zakończenia, przypisów, bibliografii, źródła ilustracji $\mathrm{i}$ indeksu nazwisk.

Książkę otwiera rozdział poświęcony początkom tworzenia sowieckiego/radzieckiego aparatu bezpieczeństwa. Autor (s. 15) stwierdził, że historia sowieckiej służby bezpieczeństwa rozpoczęła się 20 grudnia $1917 \mathrm{r}$. wraz z powstaniem $\mathrm{WCzK}^{3}$ zwanej potocznie Czeka. W tym miejscu warto wspomnieć, iż zręby sowieckiego aparatu bezpieczeństwa, zaczęły się kształtować wraz z utworzeniem Piotrogrodzkiego Komitetu Wojskowo-Rewolucyjnego, który bolszewicy rozwiązali 15 grudnia 1917 r., zaś czołowy jego działacz Feliks Dzierżyński został zobligowany przez Włodzimierza Lenina do utworzenia specjalnej komisji. Już u samych podstaw powstania Czeka, jej twórca F. Dzierżyński jasno nakreślił plan działania, który nie pozostawiał złudzeń co do prowadzenia metod walki z przeciwnikiem politycznym, które potem były stosowane przez NKWD/ MWD/MGB. W swoim przemówieniu Dzierżyński powiedział: „Niech wam się nie wydaje, że poszukuję form sprawiedliwości rewolucyjnej; teraz nie sprawiedliwości nam trzeba. To jest wojna - twarzą w twarz, do końca. Życie albo śmierć! Proponuję, domagam się organu, którego zadaniem będzie rewolucyjne, bolszewickie wyrównywanie rachunków z kontrrewolucjonistami”" Kolejna nieścisłość występuje w stwierdzeniu Autora niniejszej publikacji (s. 16-17),który stwierdził, że po zakończeniu wojny domowej i umocnieniu władzy przez bolszewików oraz utworzeniu 30 grudnia 1922 r. ZSRR, siły WCzK liczyły 126300 ludzi. Brakuje komentarza, że w tym okresie ZSRR był na tzw. stopie pokojowej i po reorganizacji na mocy dekretu z 6 lutego 1922 r. struktur politycznej bezpieki, rozwiązano Czeka a powołano GPU (Gosudarstwiennoje Politiczeskoje Uprawlenije - Państwowy Zarząd Polityczny). Podjęto decyzje o redukcji kadr sowieckiej bezpieki, która pod koniec 1921 r. liczyła około 260 tys. pracowników (mundurowych i cywilnych)5, a zredukowano ją do liczby, którą podał G. Motyka. Omawiając tworzenie struktur sowieckiego aparatu bezpieczeństwa w rozdziale: Tarcza i miecz partii. Wojska NKWD (s. 14-36) Autor pominął całkowicie problem czystek, które objęły również i ten filar bezpieczeństwa, gdzie w latach trzydziestych XX w. usunięto 90\% kierownictwa policji politycznej ${ }^{6}$. Grzegorz Motyka podejmując w książce problem walki sowietów

3 WCzK (Wsierossijskaja czeriezwyczajnaja komissija po bor'bie s kontrriewolucyjej i sabotażemOgólnorosyjska Komisja Nadzwyczajna do Walki z Kontrrewolucją i Sabotażem).

4 N. Werth, Zwiazek Sowiecki 1917-1945, [w:] Czekiści. Organy bezpieczeństwa w europejskich krajach bloku sowieckiego 1944-1989, red. K. Persak i Ł. Kamiński, Warszawa 2010, s. 20.

5 N. Werth, L'OGPU en 1924, „Cahiers du monde russe” 2001, t. 42, nr 2-3-4, s. 397-422.

6 Tenże, Związek Sowiecki..., s. 41. 
z podziemiem na ziemiach polskich za linią Curzona w okresie 1944-1945, w podrozdziale: Niszczenie podziemia: Ukraina Zachodnia (s. 139-142) zupełnie pominął problem tworzenia przez sowietów istriebitielnych batalionów (IB) i grup wsparcia (GS), tzw. oddziałów wsparcia, które były formowane z miejscowej ludności. Warto podkreślić, że kierownictwo sowieckie pokładało w IB duże nadzieje $\mathrm{w}$ walce $\mathrm{z}$ podziemiem. $\mathrm{W}$ tym miejscu warto przytoczyć wypowiedź I sekretarza KP (b) Litwy Sniečkusa, który powiedział: „Należy zrozumieć, że istriebitielnyje bataliony są dla nas ważne nie tylko jako siła zbrojna, ale mają też one znaczenie społeczno-polityczne. Właśnie poprzez istriebitielnyje bataliony mamy możliwość wciągnięcia $\mathrm{w}$ walkę przeciwko bandytom szerokich kręgów ludności i przekształcenia tej walki w ogólnonarodową"7. Mówiąc o zwalczaniu partyzantki ukraińskiej na terenach Ukrainy Zachodniej, nie sposób pominąć zagadnienia udziału Polaków w istriebitielnych batalionach. Brak zaufania władzy komunistycznej do miejscowych Ukraińców sprawiał, że do IB przyjmowano Polaków. Zwłaszcza wydarzenia z lata 1944 r. w rejonie Galicji, gdzie zamieszkujący Polacy, stanęli przed wyborem: wstąpienie do armii Berlinga, albo wywiezienie do łagrów. Brak sensownej alternatywy sprawiło, że wielu Polaków znalazło się w oddziałach IB. Często po zakończeniu akcji „Burza” na terenach wschodnich, wielu ujawnionych członków AK tworzyło IB i zaczęło wysyłać do władz sowieckich informacje i donosy na żołnierzy, i sympatyków UPA. Sowieci wykorzystując animozje narosłe zwłaszcza po 1943 r. od rzezi wołyńskiej między Polakami a Ukraińcami, starali się grać polską kartą przeciwko banderowcom. Szkoda, że Autor nie pokusił się o podjęcie wyjaśnienia motywów wstępowania i służby Polaków w IB. Zapewne jednym z motywów zasilania oddziałów IB przez Polaków była ochrona tej nacji przed UPA. Działalność elementu polskiego w oddziałach IB była negatywnie postrzegana przez dowództwo UPA/OUN. Dobitnie ilustruje jeden z raportów UPA, w którym m.in. czytamy: „Bardzo niebezpiecznym dla nas przeciwnikiem jest polska policja. Zna miejsca i ludzi, bierze udział w antyukraińskich operacjach milicji bolszewickiej. Dlatego te oddziały polskiej policji [oddziały IB - przyp. W.Ch.], które otwarcie współpracują z bolszewikami, zwalczamy" 8 .

7 Szerzej na temat działalności IB na Litwie pisze J. Starkauskas, Stribai. Ginkluotieji kolaborantai Lietuvoje partizantinio karo laikotarpiu (1944-1953), Vilnius 2001; T. Balbus, Polskie istriebitielnyje bataliony NKWD w latach 1944-1945, „Biuletyn IPN” 2002, nr 6, s. 74.

8 P. Sodol, Ukrajinska Powstancza Armija 1943-1949. Dowidnyk, Nju Jork 1994, s. 47 i n.; W. Wiatrowycz, Antykomunistyczny ruch oporu na Ukrainie w latach 1944-1953, [w:] Polskie podziemie niepodległościowe na tle konspiracji antykomunistycznych $w$ Europie Środkowo-Wschodniej $w$ latach 1944-1956, red. S. Poleszak, Warszawa - Lublin 2008, s. 67-75. 
Autor omawiając metody represji wobec oddziałów partyzanckich, stosowane przez NKWD, które miały mniej szczęścia i nie udało się umknąć obławie (s. 170), całkowicie pominął w swojej publikacji metody rozpracowywania polskiego podziemia, m.in. NKWD gros wysiłków na południowym Podlasiu i wschodnim Mazowszu skierowała na zbieranie informacji o dowódcach i oddziałach AK, NSZ oraz tworzeniu sieci agenturalnej. Kontroli podlegała cała korespondencja oraz rozmowy telefoniczne. Ponadto z urzędów pocztowych oficerowie NKWD zabierali ewidencję posiadaczy radioodbiorników. Przy drogach wyjazdowych z miast i osad znajdowały się punkty kontrolne samochodów, na rozwidleniach dróg znajdowały się stałe punkty obserwacyjne. Do pacyfikacji często używano oddziały NKWD ubrane w polskie mundury. Zazwyczaj NKWD dokonywało pacyfikacji nad ranem, kiedy ludność danej miejscowości jeszcze spała. Otaczano wieś marszem gwiaździstym i na dany sygnał dowódcy dokonywano pacyfikacji ${ }^{9}$. Metodę działania sowieckiego aparatu bezpieczeństwa ilustruje powyższy cytat: „Niemcy działali głośno, demonstrowali swoją siłę budząc strach i grozę, a to powodowało, że rodził się opór i solidarność: NKWD działało cicho i podstępnie" ${ }^{10}$. Poza wzajemnymi uprzedzeniami, między podziemiem polskim i ukraińskim dochodziło do współpracy przeciwko komunistom.

Według raportów opracowanych przez Służbę Bezpieczeństwa OUN w tych powiatach, które były opanowane w większości przez Ukraińców, np. w PUBP Włodawa we września 1945 r. na 65 zatrudnionych pracowników 60 było Ukraińcami ${ }^{11}$. Co jest ciekawe, że z SB OUN współpracowały niektóre posterunki $\mathrm{MO}$ na terenie powiatu Biała Podlaska, m.in. oficer Komendy Powiatowej MO w Białej Podlaskiej Bazyli Paradyszczuk był cennym informatorem SB OUN ${ }^{12}$. Dzięki jego informacjom Ukraińcy mieli dokładny wgląd w obsadę posterunków MO Komendy Powiatowej w Białej Podlaskiej na terenie powiatu bialskiego. Oddziały podziemia antykomunistycznego operujące na terenie Inspektoratu Radzyń Podlaski wchodziły w kontakt z podziemiem ukraińskim. Inicjatywa rozmów z polskim podziemiem wyszła od dowódcy oddziału

9 W. Charczuk, Działalność radzieckiego aparatu bezpieczeństwa i kontrwywiadu (NKWD i Smiersz) przeciwko podziemiu niepodległościowemu na Podlasiu i wschodnim Mazowszu lipiec 1944 - grudzień 1945, „Wschodni Rocznik Humanistyczny” 2006, t. III, s. 327-329; S. Batok, Działania NKWD na południowym Podlasiu w strefie przyfrontowej (od lipca 1944 do maja 1945), „Szkice Podlaskie”, z. 9, 2001, s. 160.

10 P. Kołakowski, NKWD $i$ GRU na ziemiach polskich 1939-1945, Warszawa 2002, s. 237.

11 R. Zientek, Stużba Bezpieczeństwa OUN w Nadrejonie „Łewada” w latach 1945-1947 „Rocznik Bialskopodlaski" 2000-2001, t. VIII-IX, s. 113.

12 Tamże, s. 115. 
UPA Serhija Martyniuka „Kryha”, „Hrab”, który we wsi Kopytków w Obwodzie Biała Podlaska do zgromadzonej ludności powiedział, że: Polacy $i$ Ukraińcy walcza wspólnie z komuną ${ }^{13}$. Mimo deklaracji „Hraba” między polskim a ukraińskim podziemiem panowała nieufność co do intencji dowództwa UPA. Wobec takiego obrotu sprawy inspektor Jan Szatyński-Szatowski postanowił spotkać się z Ukraińcami. Do pierwszego spotkania doszło w nocy z 27 na 28 października 1945 r. na kolonii Choroszczynka. Stronę polską reprezentował kpt. Władysław Nikszto „Żuk” i komendant Rejonu V Obwodu Biała Podlaska Cyprian Wierzchowski „Puszczyk”, zaś UPA-OUN „Hrab” i jego podkomendny „Hryhor” (NN). Z powodu braku wzajemnego zaufania między polskim i ukraińskim podziemiem, spotkanie było ochraniane przez przybyłą z radzieckiej Ukrainy sotnię „Hałajda II”, którą dowodził Wasyl Kral „Czaus” ${ }^{14}$. W trakcie spotkania ustalono, że obie strony nie będą naruszały swoich terytoriów, m.in. UPA zobowiązała się nie wkraczać na tereny powiatów: łukowskiego, bialskiego, radzyńskiego i włodawskiego ${ }^{15}$. Ustalono, że obie strony będą się wymieniły raportami wywiadowczymi, m.in. Ukraińcy mieli informować stronę polską o sytuacji militarnej za Bugiem. Ponadto materiał dowodowy dotyczący osób współpracujących z komunistami przekazywano by sobie sobie tak, aby wyroki na osobach Polakach wykonywali żołnierze AK-WiN, a na Ukraińcach UPA-OUN.

W rozdziale: Wojska NKWD-MWD-MGB wobec OUN $i$ UPA $w$ Polsce 1944-1947 (s. 363-379) G. Motyka słusznie zauważył, że do 1946 r. główny ciężar walki z podziemiem na terenie Polski spoczywał na radzieckim aparacie bezpieczeństwa, zaś polski aparat bezpieczeństwa pełnił rolę pomocniczą.

W części pracy autor ten, w rozdziałach: Polska w sowieckiej perspektywie (s. 37-51) i Polskie podziemie i partyzantka sowiecka (s. 52-80) podjął się ukazania planów Kremla wobec Polski. Szkoda, że nie skorzystał z opracowania Krzysztofa Grygajtisa ${ }^{16}$, który omówił wspieranie polskiego podziemia na początku 1941 r. przez „sojuszników” (III Rzeszę i ZSRR) w związku z przygotowywanymi planami ataku na siebie. Agresorzy Polski z września 1939 r. próbowali pozyskać struktury polskiego podziemia do przyszłej wojny, m.in. aresztowany przez NKWD we Lwowie w styczniu 1941 r. płk Leopold Okulicki, przesłuchiwany przez gen. Iwana Sierowa, otrzymał wiosną 1941 r. propozycję

13 Archiwum Państwowe Lublin (dalej: APL), AK-WiN, sygn. 93, t. 3, Meldunek wywiadowczy Obwodu Biała Podlaska z 5 sierpnia 1945 r., k. 155.

14 APL, Zespół UPA, t. 72, k. 36-45.

15 A. Tłomacki, Akcja „Wista” w powiecie bialskim na tle walki politycznej i zbrojnej w latach 1944-1947, Biała Podlaska - Warszawa 2003, s. 62-63.

16 K. Grygajtis, Sowiecka strategia geopolityczna w Europie a Polska 1924-1943, Warszawa 2006. 
dalszego dowodzenia strukturami ZWZ, ale pod kontrolą NKWD ${ }^{17}$. Na stronie 49 Autor pisze, że jesienią 1943 r. na konferencji w Theranie Stalin uzgodnił z Churchillem i Rooseveltem, że wschodnie granice państwa polskiego będą się opierać na linii Curzona, w zamian za co Polska miała uzyskać rekompensatę terytorialną na zachodzie. Moim zdaniem, sprawa Polski została przesądzona na początku 1943 r., kiedy to Franklin Delano Roosevelt - Prezydent USA jeszcze przed konferencją w Casablance (14-26 stycznia) w porozumieniu ze Stalinem ogłosił światu żądanie bezwarunkowej kapitulacji Niemiec, co w języku przywódców mocarstw miało oznaczać podział III Rzeszy między USA i ZSRR. Ponadto ustalono, że Polska dostosuje się do postulatów terytorialnych wysuwanych przez Moskwę i uzna granicę wschodnią na linii Curzona, zaś w zamian miała otrzymać rekompensatę w postaci Prus Wschodnich. Dla Brytyjczyków z punktu politycznego i strategicznego ważniejsza była Turcja niż sprawa Polski. Rządy USA i Wielkiej Brytanii dały Stalinowi zielone światło do podporządkowywania Europy Środkowo-Wschodniej z jednoczesnym nieliczeniem się Londynu z polityką Polską, ponieważ Polska nie leżała w strefie wpływów Imperium Brytyjskiego. Kolejne zagadnienie, do którego chciałbym się odnieść, to proces tworzenia oddziałów partyzanckich, o których pisze Autor (s. 53-54). Szkoda, że G. Motyka nie wspominał, że koncepcja tworzenia oddziałów partyzanckich wypłynęła od Batalionów Chłopskich, które wypracowały taktykę walki bieżącej, polegającej na koncentracji żołnierzy do wykonania akcji i rozejściu po wykonanym zadaniu. Na ich bazie powstały Oddziały Specjalne i OP BCh. Tworzenie OP było związane z masowym wysiedlaniem pod koniec $1942 \mathrm{r}$. ludności na Zamojszczyźnie ${ }^{18}$. Do obrony Zamojszczyzny włączyła się AK, która przystąpiła do tworzenia OP na terenie obwodów, podejmując taktykę walki partyzanckiej. Skuteczna obrona ruchu oporu przed akcją wysiedleńczą Polków z Zamojszczyzny przyczyniła się do rozwoju partyzantki na tym terenie jak i w Generalnym Gubernatorstwie ${ }^{19}$.

Wejście Armii Czerwonej na teren Polski i zainstalowanie w Chełmie 22 lipca 1944 r. rządu komunistycznego w postaci Polskiego Komitetu Wyzwolenia Narodowego. Już 26 lipca 1944 r. PKWN zawarł z ZSRR porozumienie o stosunkach między dowództwem radzieckim a polską administracją cywilną na

\footnotetext{
Tamże, s. 118.

J. Gmitruk, Zamojszczyzna historia pisana chłopską krwią, Warszawa 2000, s. 29 i nast.

19 A. Charczuk, Zwiazek Walki Zbrojnej - Armia Krajowa na Południowym Podlasiu w latach 1939-1944, Siedlce 2004, s. 247-248 (mps rozprawy doktorskiej obronionej na Wydziale Humanistycznym Akademii Podlaskiej w Siedlcach, obecnie Uniwersytet Przyrodniczo-Humanistyczny).
} 
wyzwolonych terenach Polski. Porozumienie poddawało sowieckiej jurysdykcji przestępstwa popełnione przez ludność polską przeciwko Armii Czerwonej. 15 sierpnia 1944 r. PKWN ogłosił pobór mężczyzn do wojska, co przyczyniło się do utworzenia przez komunistów 2 Armii Wojska Polskiego, w której część kadry oficerskiej była sowiecka, co pozwoliło poddać ją kontroli NKWD i Smiersz. Szkoda, że G. Motyka omawiając problem wejścia Armii Czerwonej w rozdziale: Do Polski wkraczają Sowiety.... Polska Lubelska 1944 (s. 103-129) pominął wątek zbrodni, jakiej dopuściło się na Polakach-żołnierzach podziemiach NKWD w miejscu postoju sztabu 2 Armii Wojska Polskiego na terenie powiatu łukowskiego, przy którym funkcjonowała komórka Smiersz pod nazwą Informacji Wojskowej z dowódcą ppłk. Dymitrem Wozniesieńskim ${ }^{20}$. Jego zastępcą był ppłk Zajcew, zaś szefem Wydziału Śledczego IW mjr Czewiczałow. Oficerami śledczymi byli: kpt. Bołdyrow, kpt. Kolesowin, kpt. Frołow, kpt. Jeżykow, kpt. Isakow, kpt. Kiszkin - oficerowie NKWD. Wskutek działalności agenta, który działał wśród miejscowej siatki NSZ funkcjonariuszom NKWD udało się aresztować 16. żołnierzy podziemia, z których 8 skazano na karę śmierci ${ }^{21}$. Siedmiu zamordowano 24 listopada 1944 r. w iście katyński sposób. Ofiary miały ręce związane do tyłu oraz nogi kablem metalowym, a usta zakneblowane szmatami, aby przy wrzucaniu do rowu nie było słychać żadnych głosów, oprócz oprawców z NKWD, według relacji zastępcy naczelnika aresztu plut. Jankowskiego, egzekucja odbywała się nad dołami przez uderzenie $\mathrm{z}$ dużą siłą stępionym narzędziem w głowę, a gdy ofiara dawała jeszcze oznaki życia, to st. sierż. Bazyli Rogoziński dobijał z pistoletu strzałem w tył głowy. Następnie dół zasypywano ziemią, wyrównywano i maskowano mchem i sadzonkami drzew ${ }^{22}$.

W rozdziale: Wojska NKWD w walce z podziemiem narodowym (s. 255-286), Autor jest jednostronny $\mathrm{w}$ ocenie dorobku podziemia narodowego $\mathrm{w}$ walce z komunistycznym i sowieckim zniewoleniem Polski. Uważa, że żołnierze NSZ i innych formacji podziemia narodowego uznawali ukrywających się Żydów przed Niemcami za sprzyjających komunistom, których likwidowano (s. 259). Wcale nie przeczę, że były takie akcje przeprowadzane przez patrole Pogotowia Akcji Specjalnej NSZ wobec osób pochodzenia żydowskiego, ale po dokładnym rozpoznaniu i sprawdzeniu, że dana osoba była informatorem, agentem lub pracownikiem aparatu bezpieczeństwa. Są jednak przykłady, kiedy sami Żydzi

20 W. Charczuk, Walka polityczna na Południowym Podlasiu i Wschodnim Mazowszu w latach 1944-1956, Siedlce 2012, s. 88.

21 Tamże.

22 A. Stolcman - relacja z 22 marca 1998 r. w zbiorach autora. 
wręcz prosili dowódców oddziałów NSZ, żeby udzielili im schronienia, ochronili przed Niemcami. Dobrym przykładem łamiącym utarty stereotyp żołnierza NSZ - wiecznego antysemity jest wydarzenie z Podlasia, gdzie w meldunku ppor. Stanisława Laskowskigo „Leśny” - notabene oficera GL-AL, stwierdzono, że oficerowie NSZ ukrywali Żydów w „Jacie”23, a także przechowywali ich mienie. Tymi ukrywającymi się Żydami byli Lejbko Goldman - znany siedlecki kupiec (przed wojną miał sklep monopolowy przy ul. Piłsudskiego) i Izaak Halber, którzy potem świadczyli na korzyść oficerów NSZ przed sądem wojskowym w sprawie wykonania wyroku śmierci na ośmiu partyzantach sowieckich, co było w ówczesnym systemie politycznym precedensem; w 1956 r. oficerowie NSZ zostali zrehabilitowani ${ }^{24}$. Kolejny przykład, który łamie stereotyp żołnierza NSZ jako antysemity, to we wspomnieniach żołnierza Brygady Świętokrzyskiej NSZ mamy informacje, że w oddziałach narodowych służyli jako sanitariusze i lekarze wojskowi Żydzi ${ }^{25}$. Również Autor recenzowanej książki w sposób jednoznaczny przypisuje „winę domniemaną” żołnierzom NSZ dotyczącą wydarzeń pod Rząbcem oraz w Wierzchowinach latem 1945 r., chociaż nie do końca zostały one wyjaśnione przez historyków. Szkoda, że Grzegorz Motyka pisząc rozdział poświęcony walce NKWD z podziemiem Obozu Narodowego nie uwzględnił opracowania Mirosława Piotrowskiego, który podjął się próby rekonstrukcji wydarzeń $\mathrm{w}$ Wierzchowinach ${ }^{26}$. Historycy badający tę sprawę opierają się na meldunkach ppor. Romana Jaroszyńskiego „Roman” i kpt. Mieczysława Pazderskiego „Szary”. Ten ostatni miał wkroczyć do wsi zamieszkiwanej przez Ukraińców na czele oddziału NSZ 6 czerwca 1945 r. i dokonać pacyfikacji miejscowości mordując 194 osoby $^{27}$. Zwłaszcza po 1989 r. część

23 Rezerwat Jata - kompleks leśny położony na terenie powiatu łukowskiego. Pod względem prawnym został utworzony 21 marca 1933 r. z inicjatywy prof. W. Szafera - wybitnego polskiego przyrodnika. Po wybuchu II wojny światowej grupa żołnierzy AK oraz fakt zdekonspirowania niektórych z nich w terenie wymusił decyzję o budowie obozu partyzanckiego w rezerwacie Jata. Budowa obozu rozpoczęła się pod koniec 1943 r. i zlokalizowana była obok istniejącego już obozu NSZ. W 1944 r. dokończono budowę obozu i dnia 28 maja 1944 r. uroczyście poświęcono sztandar oddziału. Dowódcą oddziału leśnego (OL Jata) został por. Piotr Nowiński „Paweł”, zaś jego przełożonym - por. Wacław Rejmak „Ostoja”. Z uwagi, że na terenie rezerwatu stacjonował również oddział radziecki - ustalono wspólne hasła, by nie strzelać do siebie nawzajem.

24 Tajne oblicze GL-AL., PPR. Dokumenty, wybór i oprac. M. J. Chodkiewicz, P. Gontarczyk, L. Żebrowski, t. 1-3, Warszawa 1997-1999; W. Charczuk, Miejsce Narodowych Sił Zbrojnych w historii, „Pro Memoria” 2003, nr 6, s. 23-24.

25 W. Widloch, Inna drogą. Narodowe Siły Zbrojne, Nowy Sącz 1991, s. 40-41.

26 M. Piotrowski, Narodowe Sity Zbrojne na Lubelszczyźnie 1944-1947, Lublin 2009, s. 68-92.

27 Archiwum Instytutu Pamięci Narodowej (dalej: AIPN), sygn. 73, MBP, NSZ, Odpis raportu sytuacyjnego kpt. „Szarego” z 9 czerwca 1945 r., k. 75. 
historyków zajmująca się dziejami NSZ podważa tezę lansowaną przez historyków poprzedniego systemu politycznego jakoby za tę zbrodnię na ludności ukraińskiej odpowiadały wyłącznie NSZ i sugeruje innych sprawców niż narodowcy ${ }^{28}$. Owszem wieś była zamieszkiwana przez Ukraińców, z których większość kolaborowała $\mathrm{z}$ nową władzą komunistyczną, inni pracowali jako wywiadowcy i śledczy w UB, co też mogło sugerować odwet polskiego podziemia na tych osobach, którzy swoją działalnością doprowadzili do aresztowań Polaków. Zbrodni mogły dokonać „oddziały pozorowane” tworzone przez komunistów nie tylko w aparacie bezpieczeństwa, ale w Wojsku Polskim, które na konto podziemia dokonywały zbrodni i rabunków mieszkańców miejscowości objętych operacjami ${ }^{29}$. Owszem do Wierzchowin wkroczył oddział „Szarego”, który dokonał likwidacji 19. mieszkańców na mocy wyroków wydanych przez WSS AK na osobach-agentach UB i sowieckiego aparatu bezpieczeństwa. Zaraz po wyjściu partyzantów, weszły komunistyczne „oddziały pozorowane”, które dokonały masakry, mordując 180 mieszkańców $^{30}$. Grzegorz Motyka uległ zbyt pochopnej decyzji w przypisaniu winy oddziałom NSZ opierając się na meldunku M. Pazderskiego „Szary”: „Postanowiono zlikwidować kilka ukraińskich wsi. Pierwszą i najbliższą miała być wieś Wierzchowiny (...). Wierzchowiny otoczono ze wszystkich stron i wycięto 194 osoby narodowości ukraińskiej. Kilkunastu zdołało uciec" (s. 276). Faktycznie pozostał meldunek Romana Jaroszyńskiego „Roman”, który zabezpieczał ze swoim oddziałem wylot ulicy i nie brał bezpośredniego udziału w pacyfikacji tej miejscowości. Potem chcąc się wybielić przed wojskowym sądem, zeznawał wszystko, co komuniści chcieli usłyszeć. Również świadek Anna Święcicka przed komisją, która przybyła do Wierzchowin zeznała, że była 6 czerwca 1945 r. we wsi i widziała „jakieś 18 do 20 trupów”31. „Szary”

28 A. G. Kister, Wierzchowiny, „Nasza Polska”, nr 5 z 4 lutego 2003, s. 10-11; M. Zaborski, Zbrodnia nie popelniona przez NSZ, „Gazeta Polska” z 15 września 1994, s. 1-2.

29 Szerzej piszą: A. G. Kister, Wojsko wobec polskiego niepodległościowego podziemia zbrojnego 1944 -1949, „Zeszyty Historyczne WiN-u” nr 19-20, 2003, s. 35-65; L. Żebrowski, Szwadrony śmierci, „Nasz Dziennik” nr 46, $23-24$ luty 2013. J. Pawłowicz, Działania pozaprawne Polskiej Partii Robotniczej wobec opozycji i podziemia na przykładzie „szwadronu śmierci” Władysława Rypińskiego, [w:] „Zwyczajny” resort. Studia o aparacie bezpieczeństwa 1944-1956, red. K. Krajewski, T. Łabuszewski, Warszawa 2005, s. 227-261; M. Korkuć, Oddziały prowokacyjne UB i KBW w Małopolsce, „Zeszyty Historyczne WiN-u” 1995, nr 8, s. 97-108; R. Wnuk, Lubelski Okręg AK 1944-1947, Warszawa 2000, s. 88-89; L. Żebrowski, Działalność tzw. band pozorowanych jako metoda zwalczania podziemia niepodległościowego w latach 1944-1947, [w:] Skryte oblicze systemu komunistycznego. U źródeł zła..., red. R. Bäcker, P. Hübner, Warszawa 1997, s. 75-90.

30 M. Zaborski, Zbrodnia nie popetniona..., s. 9.

31 AIPN Lu, sygn. 06/355, Protokół przesłuchania Anny Święcickiej, t. 10, k. 83-87. 
oraz większość dowódców i żołnierzy NSZ, którzy uczestniczyli w akcji we wsi Wierzchowiny zginęli w okrążeniu oddziałów przez NKWD i UB pod Hutą 10 czerwca 1945 r. Komisja, która badała sprawę Wierzchowin również nie ustaliła jednoznacznie sprawców mordu ludności, jedynie potwierdzała wersję zdarzeń sporządzoną przez UB. Pomimo braku ustaleń co do konkretnego sprawcy masakry w Wierzchowinach, komuniści postanowili wykorzystać ten mord propagandowo, np. „Sztandar Ludu”, gazeta będąca organem prasowym PPR. Na jej pierwszej stronie pojawiły się nagłówki: „Wierzchowiny-nowy Majdanek”, „Domagamy się wytępienia zbrodniczych band”, w ten sposób urabiając opinię publiczną, porównując NSZ do formacji SS ${ }^{32}$.

Komuniści zdawali sobie sprawę, że mają nikłe poparcie w społeczeństwie, stąd też podjęli decyzję o przeprowadzeniu referendum zamiast wyborów. Referendum pozwoliło komunistom na pół roku odsunąć wybory do sejmu, a jednocześnie sprawdzić poparcie dla PPR. Równocześnie przygotowując grunt pod referendum podjęli zakrojone na szeroką skalę działania przeciwko podziemiu, aby ostatecznie rozprawić się z opozycją zbrojną. Poza działaniami zbrojnymi, komuniści angażowali „oddziały pozorowane”, które posuwały się do skrytobójczych mordów działaczy PSL, osób duchownych, żeby potem w oczach społeczeństwa zdyskredytować podziemie zbrojne. Dla przykładu przytoczę mord ks. Lucjana Niedzielaka „Głóg” kapelana AK i WiN, proboszcza Polskowoli. Jego plebania była miejscem spotkań dowódców WiN. Ksiądz Niedzielak stał się osobą niewygodną dla PUBP w Radzyniu Podlaskim. W okresie wzmożonej walki politycznej (wybory do Sejmu) 5 lutego 1947 r. ks. L. Niedzielaka zamordował pracownik PUBP w Radzyniu Podlaskim Edmund Szczęśniak ${ }^{33}$. W Zespole Starostwo Powiatowe Radzyń Podlaski Archiwum Państwowe w Lublinie Oddział w Radzyniu Podlaskim zachowała się ulotka, która została opublikowana przez ówczesną władzę do mieszkańców powiatu radzyńskiego w związku ze śmiercią ks. Niedzielaka, gdzie w treści czytamy: „Obywatele! Dnia 5 lutego 1947 roku został popełniony o pomstę do nieba wołający mord na Proboszczu Parafii w Polskowoli, ogólnie cenionym i szanowanym ks. Nidzielaku

32 Szerzej patrz: Z. Leszczyńska, Procesy sądowe w latach 1944-1956 wobec członków organizacji niepodległościowych na Lubelszczyźnie, [w:] Przestępstwa sądów i prokuratorów w Polsce w latach 1944-1956, red. W. Kulesza, A. Rzepliński, Warszawa 2001, s. 149-150; R. Wnuk, Stosunek polskiego podziemia niepodległościowego i legalnej opozycji do mniejszości ukraińskiej w latach 1944-1947, [w:] Akcja „Wista”, red. J. Pisuliński, Warszawa 2003, s. 99-104.

33 D. Magier, Codzienność w cieniu sowietyzacji. Eseje i dokumenty z życia Radzynia Podlaskiego i okolic w latach 1944-1956, Radzyń Podlaski 2008, s. 140-141. 
Lucjanie. Mord ten popełniony został - jak okazało wstępne śledztwo przez zwyrodniałe, pozbawione wszelkich uczuć ludzkich jednostki spod znaku NSZ i WiN-u, organizacyj kontynuujących dalej dzieło hitlerowskie”34. Przykładowy fragment cytowanej ulotki obrazowo wyjaśnia metody działania władzy ludowej, z jednoczesnym wskazaniem sprawców tragedii. Szkoda, że Autor nie podjął $\mathrm{w}$ recenzowanej publikacji szerszego kontekstu takich metod działania komunistów i zupełnie pominął wątek dotyczący represji wobec Kościoła.

Książka Grzegorza Motyki, Na białych Polaków obława. Wojska NKWD $w$ walce $z$ polskim podziemiem 1944-1953, spełnia swoje podstawowe zadanie, pozwala na dokonanie rekonstrukcji metod działania sowieckiego aparatu bezpieczeństwa $\mathrm{w}$ walce $\mathrm{z}$ polskim podziemiem zbrojnym po $1944 \mathrm{r}$. na szerszej płaszczyźnie polityczno-militarnej. Swoje uwagi dotyczące książki przedstawiłem w treści artykułu recenzyjnego. Pomimo pewnych sugestii zawartych w niniejszym tekście, publikację należy uznać za wartościową. Należy docenić wysiłek Autora włożony w przeprowadzenie kwerendy zwłaszcza w archiwach Rosji, Ukrainy i Białorusi, a więc państw, które zostały objęte badaniem. Kolorytu wydanej publikacji dodaje ładne wydanie (twarda oprawa) i zamieszczone zdjęcia, które pozwalają czytelnikowi przybliżyć tematykę podjętą przez prof. Grzegorza Motykę.

34 Tamże, s. 141. 